\title{
Reinventing "Many Voices": MacBride and a Digital New World Information and Communication Order
}

\section{Daya Kishan Thussu}

To cite this article: Daya Kishan Thussu (2015) Reinventing "Many Voices": MacBride and a Digital New World Information and Communication Order, Javnost - The Public, 22:3, 252-263, DOI: $10.1080 / 13183222.2015 .1080454$

To link to this article: http://dx.doi.org/10.1080/13183222.2015.1080454

曲 Published online: 28 Sep 2015.

Submit your article to this journal

山 Article views: 6

Q View related articles $\sqsubset$

View Crossmark data $₫$ 


\title{
REINVENTING "MANY VOICES": MACBRIDE AND A DIGITAL NEW WORLD INFORMATION AND COMMUNICATION ORDER
}

\author{
Daya Kishan Thussu
}

\begin{abstract}
The MacBride Commission Report was arguably one of the most significant multilateral interventions in the history of international communication. This article charts its emergence at the time of deeply contested Cold War politics, coinciding with the rise of the southern voices in the global arena, led by the non-aligned nations. Thirty-five years after the report's publication, has the global media evolved into a more democratic system, demonstrating greater diversity of views and viewpoints? Despite the still formidable power of US-led western media, the article suggests that the globalisation and digitisation of communication has contributed to a multi-layered and more complex global media scene, demonstrating the "rise of the rest".
\end{abstract}

KEYWORDS MacBride; New World Information and Communication Order; BRICS; China; digitisation; globalisation

\section{The Historical Context of MacBride}

It is important to rehearse the origins of the MacBride Report to fully understand its importance for international communication debates, which, for much of the 1970s and early 1980s, dominated international forums such as UNESCO and UNCTAD. The demand for a more equitable global economic order was voiced by the Group of 77, established in 1964 as part of the Non-Aligned Movement. As a result of their persistent efforts, the UN General Assembly in 1974 formally approved the creation of a New International Economic Order, which spoke of the right to "pursue progressive social transformation that enables the full participation of the population in the development process" (Hamelink 1979, 145).

This new economic order was linked to demands for a New World Information and Communication Order (NWICO). Reflecting the spirit of the period, the Chilean scholar Juan Somavia, who later became one of the members of the MacBride Commission, wrote:

It is becoming increasingly clear that the transnational communications system has developed with the support and at the service of the transnational power structure. It is an integral part of the system which affords the control of that key instrument of contemporary society: information. It is the vehicle for transmitting values and lifestyles to Third World countries which stimulate the type of consumption and the type of society necessary to the transnational system as a whole. (Somavia 1976, 16-17) 
NWICO protagonists argued that the international information system reinforced and perpetuated global inequality, which seriously thwarted the developmental processes of the countries of the south, which were heavily dependent on the advanced western nations for both software and hardware in the information sector. It was also suggested by southern leaders that, through their control of international information channels, the western media presented a distorted view of their countries to the rest of the world and that there was no contra-flow of news and information to redress the balance (Nordenstreng and Padovani 2005; Nordenstreng 2012; Frau-Meigs et al. 2012). These complaints were most clearly articulated by the then Tunisian Information Minister Mustapha Masmoudi, who was a prominent member of the MacBride Commission, thus:

- owing to the socio-technological imbalance there was a one-way flow of information from the "centre" to the "periphery," which created a wide gap between the "haves" and the "have nots;"

- the information rich were in a position to dictate terms to the information poor, thus creating a structure of dependency with widespread economic, political and social ramifications for the poor societies;

- this vertical flow (as opposed to a desirable horizontal flow of global information) was dominated by the Western-based transnational corporations;

- information was treated by the transnational media as a "commodity" and subjected to the rules of the market;

- the entire information and communication order was a part of and in turn propped up international inequality that created and sustained mechanisms of neo-colonialism. (Masmoudi 1979, 172-173)

Masmoudi voiced complaints that had been repeatedly discussed within the Non-Aligned Movement, most vociferously in their summits in Algiers in 1973 and Tunis in 1976. Largely owing to their unrelenting chorus of protest, the Mass Media Declaration by UNESCO General Conference in 1978 and the 33rd session of the United Nations General Assembly-in December of the same year-adopted a resolution on the NWICO. The MacBride Commission-or, to give it its formal name, the International Commission for the Study of Communication Problems-submitted its final report to UNESCO in 1980 as Many Voices-One World: Towards a New, More Just and More Efficient World Information and Communication Order (Nordenstreng, 2012; Frau-Meigs et al. 2012).

The commission which was established by UNESCO under the chairmanship of Irish statesman Sean MacBride, winner of both the Nobel Peace Prize in 1974 and the Lenin Peace Prize in 1977, brought information-related and communication-related issues onto the global agenda for the first time, and gave intellectual justification for evolving a new and fairer global communication and information order. In many ways it was, and remains, a seminal document. Established in 1977 as a response to Resolution 100 of the 19th General Session of UNESCO held in Nairobi in 1976, the MacBride Report focused on four main aspects of global communication: the current state of world communication; the problems surrounding a free and balanced flow of information and how the needs of the developing countries link with the flow; how, in light of the New International Economic Order, a NWICO could be created; and how the media could become the vehicle for educating public opinion about world problems. The 100 background papers specially commissioned for the report generated much international interest in NWICO, enriching the debate 
and raising it from mere political rhetoric to a thoughtful criticism of striking inequities in media and communication power relations (Nordenstreng 2012; Frau-Meigs et al. 2012; Thussu forthcoming).

In the foreword for the report, then Director General of UNESCO Amadou-Mahtar M'Bow noted:

The problems arising in connection with communication, when the diversity of contemporary society is considerable, are not of a kind that can be dealt with exhaustively in a single study, however thorough and comprehensive it may be. The work of the Commission must therefore be continued and taken deeper. (MacBride Report 1980, xv).

Among the 82 recommendations that covered the vast range of global communication issues was included "democratization" of communication. This encouraged "horizontal communication" and supported "counter-information" to dominant providers of information and communication. Supporting the UNESCO definition of "a free flow and a wider and more balanced dissemination of information", the report linked freedom of the press and expression to the rights to communicate and receive information, rights of reply and correction. The report also criticised commercialisation of media and information, pressures from advertisers and concentration of ownership, relating the expansion of transnational corporations to "one way flow", "market dominance" and "vertical flow" (MacBride Report 1980, 191-233).

Unsurprisingly, the report received a mixed response: NWICO protagonists welcomed it, while the West, led by the United States, criticised the report's alleged bias against private ownership of media and communication. Following the submission of the MacBride Commission Report to the 21 st General Conference Session of UNESCO held in Belgrade in 1980, a resolution for the attainment of a NWICO was passed. However, the West saw it as a "Soviet-inspired" move by southern nations-most of them undemocratic and corruptto control the media through state regulation: a concept fundamentally in conflict with the principle of the "free flow of information" (Thussu forthcoming). US opposition culminated in its withdrawal from UNESCO in 1985, followed a year later by Britain. As Colleen Roach comments:

To state that virtually every NWICO-related issue or subject ("social responsibility of the press", "protection of journalists", "right to communicate", etc.) was reduced to the slogan of "government control of the media" is no exaggeration. The reason for this strategy is not merely the US predilection for over-simplification of complex issues, or even the historical commitment to the First Amendment, although these factors are certainly not to be neglected. The emphasis on the "government control" argument reflects, above all, the need to ensure that the NWICO would not reinforce government-run public sector communications media at the expense of the private sector. (Roach 1987, 38)

Much has changed in the global communication environment since the fraught debates of the 1980s, arising from the tensions and tactics of the Cold War. The one-way "vertical flow" of international media, mainly from the United States to other parts of the world as highlighted by the MacBride Report and also documented by two UNESCO-sponsored studies (Nordenstreng and Varis 1974; Varis 1985), has intensified in the era of digitised globalisation. However, it is also the case that such flows have been supplemented by multiple and horizontal traffic, as "subaltern" media content providers have emerged to service an ever-growing market (Thussu 2007; UNESCO 2009). Such contra-flows in 
international communication have offered possibilities for "many voices" to emerge and be heard in an increasingly globalised media world.

\section{Media Hunger versus Information Glut}

The MacBride Commission Report was published in an era of media and communication scarcity across the globe, particularly in the developing world. Although we have witnessed extraordinary expansion of media in major developing countries, especially in the past two decades, the globalisation, deregulation and privatisation of media and communication industries have also further entrenched western media organisations in hitherto unchartered territories. Some version or derivative of American or Americanised media are available and consumed all over the world, in English or in dubbed or indigenised forms. And despite the emergence of major non-US media players, the United States remains the largest exporter of the world's entertainment and information programmes as well as of the software and hardware through which these are distributed (Thussu forthcoming). According to the 2014 report from the International Intellectual Property Alliance, the United States leads the world in the production and sale of the "core copyright industries", estimated to be worth $\$ 1.1$ trillion in 2013. These industries include computer software, videogames, books, newspapers, periodicals and journals, motion pictures, recorded music and radio and television broadcasting, and accounted for nearly seven per cent of the US gross domestic product in 2013 and overseas sales of $\$ 156$ billion (Siwek 2014).

Across the board, the US domination of global media continues: from entertainment and sport (Hollywood, MTV, Disney, ESPN), news and current affairs (CNN, Discovery, Time), to financial news (Bloomberg, Fortune, Wall Street Journal), to online news portals (Huffington Post, Buzzfeed, The Vice) as well as the networks and platforms from which these are distributed via and to social media (Google, YouTube, Facebook, Twitter). These entertainment and information networks - sources of its "soft" power-are underpinned by massive American global economic, political and military supremacy. Despite talk of American decline and the "rise of the rest", it has been argued by commentators such as Fareed Zakaria that the United States will remain the "pivotal power" in international politics for a long time because there is "still a strong market for American power, for both geopolitical and economic reasons. But even more centrally, there remains a strong ideological demand for it" (Zakaria 2008, 234). Others have argued that although the United States is likely to remain a major anchor in world politics, Washington will increasingly have to accommodate the emerging powers in sharing global governance (Acharya 2014).

Parallel to this, there has been unprecedented growth of the media in many large non-western nations during the past two decades. The emergence of such groupings as BRICS (Brazil, Russia, India, China and South Africa) coinciding with the relative economic decline of the West has created the opportunity for emerging powers such as China and India to participate in global governance structures hitherto dominated by the US-led western alliance (Narlikar 2010; Halper 2010; Layne 2012; Bell 2015; Nordenstreng and Thussu 2015). The 2013 Human Development Report from the United Nations Development Programme, interestingly titled "The Rise of the South", predicts that by 2020 the combined economic output of China, India and Brazil will surpass the aggregated production of the United States, Britain, Canada, France, Germany and Italy (UNDP 2013, 123). It has been argued that the centre of economic gravity could be shifting away from the West, also 
reflected in the so-called "pivot" of US foreign policy moving to Asia, in its attempt at "rebalancing" international relations to deal with the "rise of China" (Bell 2015).

\section{New Markets and the "Rise of the Rest"}

The peaceful "rise" of China-a civilisational state rather than a nation-state-as the world's fastest growing economy has profound implications for global polity and economy (Shambaugh 2013; Bell 2015). Since 2006, China has been the largest holder of foreign-currency reserves, estimated in 2015 to be $\$ 3.4$ trillion. On the basis of purchasing power parity, China's gross domestic product surpassed that of the United States in 2014, making it the world's largest economy, according to the International Monetary Fund. As one commentator noted: "No longer is China an emerging great power, it is a 'risen' one" (Layne 2012, 212). When Beijing opened up to global businesses in the late 1980s, its presence in the international corporate world was negligible, but by 2014 China had 95 companies in the Fortune Global 500 just behind the United States, which had 128, while three of the top 10 global corporations were Chinese (Fortune 2014).

China's economic success story has many admirers, especially in the developing world, prompting the talk of replacing the "Washington consensus" with the "Beijing consensus" (Halper 2010). Since 2000, trade volumes between China and Africa have grown 20fold, reaching $\$ 200$ billion in 2012, and from 2009 onwards China has replaced the United States as the biggest trader in Africa. China is one of India's largest trading partners with the aim to achieve the target of $\$ 100$ billion by 2016 . The world's biggest oil and gas deal signed between Russia and China in 2014-a $\$ 400$ billion pact to provide 38 billion cubic metres of natural gas per year for 30 years — shows the emerging Moscow-Beijing economic alliance.

Will the ascendance of countries such as China lead to greater circulation of their media and thus redress the imbalance in global media flows? According to the World Association of Newspapers and News Publishers, the circulation of daily newspapers has continued to demonstrate growth in Asia of more than six per cent during the period 2009-2013, at a time when Europe and North America experienced a decline of more than 20 per cent (WAN-IFRA 2014). The growth in media has also contributed to the rise of advertising revenue as consumerism escalates in new and emerging markets. PriceWaterhouseCooper's Global Entertainment and Media Outlook 2014-2018 says that by 2017 China will become the world's second-largest book as well as television market after the United States and will overtake Japan to become the third-largest market for filmed entertainment after the United States and Britain (PwC 2014).

The imbalance in global news-flow was a key aspect of NWICO debates, and in particular the distorting effect of news from the Global South being processed, edited and circulated by the "Big Four" international news agencies (Reuters, Associated Press, United Press International and Agence France Press). In the age of the Internet and the deregulated and increasingly digitised neoliberal environment, the global media landscape has been transformed, offering new challenges and opportunities for hitherto marginalised voices to be heard (Castells 2009). In addition to CNN International and BBC World News, there is now a diversity of voices in the global media sphere with the emergence of new international news broadcasters. Arguably the most professional non-western channel is Qatar's Al Jazeera English, which claims to restore the balance in reporting the Global South in its coverage of international affairs. Since its inception in 2006, Al Jazeera 
English has continually followed a broader news agenda, contributing to "many voices" in the global communication arena (Seib 2012; Figenschou 2014).

However, in ideological terms, Al Jazeera English has more often than not been a supplement rather than an alternative to western reporting on international affairs. This is not surprising, given Qatar's very close geo-political and economic ties with the United States: one of the largest US military bases in the Middle East is located not very far from the headquarters of this network in Doha, the Qatari capital. Another voice-certainly oppositional to mainstream western media-to emerge in recent years is the Russia Today (RT) network, which since its launch in 2005 has increasingly become a vocal critic of US and western foreign policy, reminiscent in many ways to the Cold War propaganda battles which cast a heavy shadow over the MacBride Report.

Apart from English, RT also broadcasts in Spanish and Arabic, claiming to have a global reach of more than 550 million viewers, and a strong presence on YouTube, where its championing of critical, sometimes controversial and always anti-western sentiments appears to have a sizable and growing following. Another prominent, if less contrarian, voice to emerge on the global television news scene is CCTV News, the state-run Chinese television news in English for an international audience, promoting the Chinese model of development and legitimising China's global presence. It forms part of an extensive external communication- "Going Out"—programme launched by the Chinese government and estimated to be worth \$7 billion: by 2015, CCTV News was claiming more than 200 million viewers outside China and broadcasting in six languages, including Arabic (Lai and Lu 2012; Zhu 2012; Shambaugh 2013; Stockman 2013).

All three non-western voices mentioned above-Al-Jazeera English, RT and CCTV News - have certainly broadened the terms of debates in international communication, with some providing an oppositional reading of international events and others supplementing the US-dominated global media, by bringing greater coverage from the Global South. There is no doubt that RT's coverage of the Syrian conflict provides a different perspective from the dominant US-UK media discourse, one predicated on Kremlin's geo-political interests in the region and part of Russian "soft power" (Sherr 2012), while CCTV is gaining viewers in Africa because, "instead of airing the usual disaster reports, the station tends to broadcast 'good news' from Africa and portrays China as a 'true friend'"' (Grill 2013).

Apart from news media, the world has also witnessed extraordinary growth in entertainment material emanating from non-western countries-prominent examples might include: India's film industry, the world's largest in terms of number of films produced (Schaefer and Karan 2013; Thussu 2013); Brazil and Mexico's telenovelas (Sinclair and Straubhaar 2013); popular music and dramas from South Korea, contributing to a Hallyu (Korean Wave; Kim 2013); and films from Nigeria-Nollywood-with markets across the African continent and among the African diaspora (Krings and Okome 2013).

\section{Reinventing MacBride for the Digital Age}

In this altered global media environment, with the growing convergence of mobile communications technologies and content, the flow of media from non-western countries is likely to increase exponentially via a multi-lingual Internet. Already China hosts the world's highest number of Internet users as well as the planet's biggest blogging population. The Chinese version of Facebook-QZone-had more than 600 million users in 2014, while China's Twitter (Sina-Weibo) had more than 100 million users in 2014. WeChat, an app 
owned by Chinese firm Tencent that allows users to create personal profiles or subscription profiles, had 400 million users. Internet users in India are expected to reach 600 million by 2020 , enabled by wireless technology. What implications will such digital connectivity have for global news flows and information and communication agendas? Will developments in digital media in the large non-western nations contribute to re-inventing a MacBride for the Internet age?

The PwC report quoted earlier predicts that global mobile Internet penetration will reach 55 per cent by 2018 and China, with total Internet advertising revenue of more than $\$ 30$ billion in 2018, will be the largest of the "higher-growth, larger-scale" markets. The United States will remain the world's biggest media market in 2018, in terms of digital revenues and Internet advertising, it predicts, but China will have "dramatically narrowed the gap" (PwC 2014). A UNESCO report supports such predictions: China will become the world's largest film market by 2020, it says, adding that other major countries such as Brazil, Russia and India are increasing the "share of the world film market (both production and admissions), with China being 'the main star of this story: based on conservative estimates, by early 2020 the Asiatic giant will surpass US as the main film market in the world'" (UNESCO 2013, 34). According to the World Press Trends survey by WAN-IFRA, 800 million people now read news online, an increasingly large number of them among emerging economies (WAN-IFRA 2014). In China, where more than one-half of the population was online in 2015, the scale of the digital revolution is such that it already is having a global impact, as indicated by the 2014 announcement of public offering on the New York Stock Exchange of Alibaba, China's largest e-commerce company-valued at \$200 billion.

In the other Asian giant, India, the growth of the Internet is also remarkable, where it took a decade for the number of Internet users to grow from 10 million to 100 million, but merely three years to double that number to 200 million (FICCI/KPMG Report 2014: 98). By 2015 , the number of Internet users in the country had crossed 300 million, making India the second largest Internet market in the world, after China. Industry estimates suggest that two million new users are added every month to social networks in India, which is expected to have the world's largest Facebook population by 2016 (FICCI/KPMG Report 2014, 119). With the expansion of $3 \mathrm{G}$ and gradual introduction of $4 \mathrm{G}$ services, paralleled with the affordability of smartphones, as telecom companies achieve economies of scale and scope, more Internet users are likely to be mobile-only subscribers using Internet-enabled devices. India's 3 G connections are expected to grow to about 369 million by 2018, as the country's biggest corporation Reliance Industries has entered telecommunication and media arena in a big way (FICCI/KPMG Report 2014, 102). In 2014 Reliance Industries acquired Network 18, India's premier news and entertainment channel, and is now introducing a $4 \mathrm{G}$ broadband network in a phased manner under the brand of Reliance "Jio" ("live").

In June 2015, when India's pro-business government led by Narendra Modi inaugurated their "Digital India" programme to bring communication facilities across the vast country, the Indian corporate houses, including Reliance Industries, pledged as much as $\$ 71$ billion to build the much-needed digital infrastructure to improve connectivity. This public-private partnership is likely to give a new lease of life to India's ambitious National Optical Fibre Network, which, once completed, will provide broadband connectivity to 250,000 Gram Panchayats (Village Councils), serving 600,000 villages and over 1.15 billion people, for better access to citizen services and improve the quality of information collected at the grassroots level (FICCI/KPMG Report 2014, 98). 
According to the 2014 Ericsson Mobility Report, there were 1.9 billion smartphone subscriptions in 2013 and a 10-fold growth in mobile data traffic between 2013 and 2019 was predicted, mostly in the developing world. Mobile broadband subscriptions had reached 2.3 billion in 2014-by 2019 these were expected to account for more than 80 per cent of all mobile subscriptions (Ericsson Mobility Report 2014,6).

It is useful to remind ourselves that governments were central to the NWICO debates and for many large developing countries, such as China, the state continues to play the dominant role in the communication and information arena. Sandra Braman has emphasised the importance of the state as the repository of power, suggesting that, in addition to instrumental, structural and symbolic forms of power, there is also informational power "that shapes human behaviour by manipulating the informational bases of instrumental, structural, and symbolic power" (Braman 2006, 25). One area which was central to the debates about NWICO was development communication, and digital connectivity offers opportunities for developmental projects ranging from tele-education to tele-medicine, from mobile banking to e-governance. Despite their impressive economic growth in the past two decades, large-population countries such as India continue to be home to huge numbers of poor and disadvantaged people (Kohli 2012). India was the first country to use television for education through its 1970s Satellite Instructional Television Experiment programme. New digital media technologies could be deployed to promote sustainable development and democratise communication, a key aspect of the MacBride Report. A possible synergy of cyberspace with efforts toward sustainable development is also a field to which emerging nations could contribute significantly.

In communication hardware, many developing countries have shown remarkable progress. China has demonstrated exceptional growth in this sector, with its China Great Wall Industry Corporation offering expertise and funding to develop satellite and other space programmes in other southern nations, while the Indian Space Research Organization has manufactured and launched a range of satellites at affordable rates. Brazil's plan to build an undersea cable - to link South America to Europe-is another example of these alternative infrastructural projects, challenging the traditional domination of this field by the United States and Western Europe. The dependence of many developing countries on aid from the West is also eroding as China is today the largest donor from the developing world followed by India. A founding member of the Non-Aligned Movement, India was a leading voice during the NWICO debates and an inspiration behind the Non-aligned News Agencies Pool, an attempt to encourage south-south news exchange to counter US-UK hegemony. There is now talk of Non-Alignment 2.0, at a time when new configurations such as the BRICS groupings have emerged, coinciding with cracks within the neoliberal model of US-led capitalism (Khilnani et al. 2012).

Will such a media discourse contribute to a more equitable and just world information order? Castells has argued that "Power is primarily exercised by the construction of meaning in the human mind through processes of communication enacted in global/local multimedia networks of mass communication, including mass self-communication" $(2009,416)$. Will the communication power of the rising billions provide "many voices" on issues affecting contemporary life-from environmental degradation to financial crisis and the threat of extremist politics? The emerging nations, notably the BRICS bloc, could be an important voice in articulating southern viewpoints in global forums such as UNESCO, International telecommunication Union (ITU) and World Intellectual Property Organization (WIPO) on such diverse and contested issues as sustainable development, climate change, 
multiculturalism, safeguarding of media plurality and intellectual property rights in the digital environment. Brazil's 2014 "Civil Law Marco Internet" — dubbed the Internet Bill of Rights-stipulates that companies, such as Google and Facebook, will be subject to Brazil's laws and courts in cases involving information on Brazilians, even if the data are stored on servers abroad. Such laws help protect citizens from any violations of their digital rights and should encourage other nations to follow suit (Thussu 2015). It is estimated that by 2020 five billion people will be online, 63 per cent of the world's population, and many of them will not use Latin keyboards, making sure that a multi-lingual Internet will emerge and contribute to its de-Americanisation-in cultural terms, if not economically (Cerf et al. 2014). Such internationalisation will further democratise what is today the most powerful global communication platform (Goggin and McLelland 2009; Schmidt and Cohen 2013; DeNardis 2014). However, while the US government and US-based corporations will continue to dominate, it will be a different Internet: China and India will account for nearly one-half of new mobile Internet users in the next five years, "but will come with significant cultural, commercial and political challenges" (PwC 2014).

The formal opening of the New Development Bank (the so-called BRICS Bank) in Shanghai in July 2015 demonstrates some of these challenges-indicating early stages of an alternative global financial architecture. The bank is to use its $\$ 50$ billion initial capital to fund infrastructure and developmental projects within the BRICS nations and to support developmental projects in other developing countries. There is a close connection between the New Development Bank and the newly-created Asian Infrastructure Investment Bank, also largely funded by China. The Global Times, known for championing Chinese nationalism, suggested that that the establishment of the New Development Bank and the Asian Infrastructure Investment Bank will "break the monopoly position of the International Money Fund and the World Bank and motivate [them] to function more normatively, democratically, and efficiently, in order to promote reform of the international financial system as well as democratisation of international relations".

However, given the realities of existing global financial order, established in Bretton Woods in 1944, any alternative financial institution has to function in a system that continues to be shaped by the West and its formidable domination of global financial markets and information and communication networks (Bhuiyan 2014). Nevertheless, it cannot be denied that an alternative infrastructure is under construction, fuelled by the financial muscle of countries such as China. A World Bank report predicts that "China will account for 30 per cent of global investment by 2030, while Brazil, India and Russia, together, will account for more than 13 per cent of global investment in 2030, more than the United States" $(2013,5)$. Ironically, China was conspicuously absent from the deliberations of the MacBride Commission-out of the 16 members of the Commission, only one-half came from the developing world. ${ }^{1}$

The NWICO, wrote Sean MacBride in the preface of the report which bears his name:

may be more accurately defined as a process than any given set of conditions and practices. The particulars of the process will continually alter, yet its goals will be constantmore justice, more equity, more reciprocity in information exchange, less dependence in communication flows, less downward diffusion of messages, more self-reliance and cultural identity; more benefit to mankind. (MacBride Report 1980, xviii)

As a seasoned international diplomat and astute observer of global affairs, MacBride was right to define his report as a long-term project, a process. Thirty-five years after its 
publication, many issues that it raised remain largely relevant despite political, economic and technological transformation of the world. However, in a digitally connected, more open, even democratised and poly-centric media globe, many more voices-some faint, some vociferous - can be heard in "one" world.

\section{DISCLOSURE STATEMENT}

No potential conflict of interest was reported by the author.

\section{NOTE}

1. The MacBride Commission had the following 16 members: Sean MacBride, chairman (Ireland), Elie Abel (USA), Hubert Beuve-Mery (France), Elebe Ma Ekonzo (Zaire), Gabriel Garcia Marquez (Columbia), Mochtar Lubis (Indonesia), Mustapha Masmoudi (Tunisia), Betty Zimmerman (Canada), Michio Nagai (Japan), Fred Isaac Akporuaro Omu (Nigeria), Bogdan Osolnik (Yugoslavia), Gamal el Oteifi (Egypt), Johannes Pietar Pronk (the Netherlands), Juan Somavia (Chile), Boobli George Verghese (India) and Leonid Zamatin (USSR; Zamatin was replaced by Sergei Losev during the study).

\section{REFERENCES}

Acharya, Amitav. 2014. The End of American World Order. Cambridge: Polity.

Bell, Daniel. 2015. The China Model: Political Meritocracy and the Limits of Democracy. Princeton, $\mathrm{NJ}$ : Princeton University Press.

Bhuiyan, Abu. 2014. Internet Governance and the Global South: Demand for a New Framework. London: Palgrave Macmillan.

Braman, Sandra. 2006. Change of State: Information, Policy, and Power. Cambridge, MA: MIT Press. Castells, Manuel. 2009. Communication Power. Oxford: Oxford University Press.

Cerf, Vinton, et al. 2014. "Strategy Report: ICANN's Role in the Internet Governance Ecosystem." ICANN. http://goo.gl/9WrOCD. Accessed 30 July 2015.

DeNardis, Laura. 2014. The Global War for Internet Governance. New Haven, CT: Yale University Press.

Ericsson Mobility Report. 2014. Ericsson Mobility Report: On the Pulse of the Networked Society, June. Stockholm: Ericsson.

FICCI-KPMG Report. 2014. The Stage is Set: FICCI/KPMG Indian Media and Entertainment Industry Report 2014. Mumbai: Federation of Indian Chambers of Commerce and Industry.

Figenschou, Tine Ustad. 2014. Al Jazeera and the Global Media Landscape: The South is Talking Back. New York: Routledge.

Fortune. 2014. "Fortune Global 500." Fortune, July.

Frau-Meigs, Divina, Jérémie Nicey, Michael Palmer, Julia Pohle, and Patricio Tupper, eds. 2012. From NWICO to WSIS: 30 Years of Communication Geopolitics Actors and Flows, Structures and Divides. Bristol: Intellect.

Goggin, Gerard, and Mark McLelland, eds. 2009. Internationalizing Internet Studies: Beyond Anglophone Paradigms. London: Routledge.

Grill, Bartholomäus. 2013. "Billions from Beijing: Africans Divided over Chinese Presence." Der Spiegel, November 29. 
Halper, Stefan. 2010. The Beijing Consensus: How China's Authoritarian Model will Dominate the Twenty-first Century. New York: Basic Books.

Hamelink, Cees. 1979. "Informatics: Third World Call for New Order." Journal of Communication 29 (4): 144-148.

Kim, Youna, ed. 2013. The Korean Wave: Korean Media Go Global. London: Routledge.

Khilnani, Sunil, Rajiv Kumar, Pratap Bhanu Mehta, Prakash Menon, Nandan Nilekani, Srinath Raghavan, Shyam Saran, and Siddharth Varadarajan. 2012. Nonalignment 2.0: A Foreign and Strategic Policy for India in the Twenty First Century, 30 January. New Delhi: National Defence College and Centre for Policy Research.

Kohli, Atul. 2012. Poverty amid Plenty in the New India. Cambridge: Cambridge University Press.

Krings, Matthias, and Onookome Okome, eds. 2013. Global Nollywood: The Transnational Dimensions of an African Video Film Industry. Bloomington: Indiana University Press.

Lai, Hongyi, and Yiyi Lu, eds. 2012. China's Soft Power and International Relations. London: Routledge.

Layne, Christopher. 2012. "This Time it's Real: The End of Unipolarity and the Pax Americana." International Studies Quarterly 56 (1): 203-213.

MacBride Report. 1980. Many Voices, One World: Communication and Society Today and Tomorrow. Paris: International Commission for the Study of Communication Problems, UNESCO.

Masmoudi, Mustapha. 1979. "The New World Information Order." Journal of Communication 29 (2): 172-185.

Narlikar, Amrita. 2010. New Powers: How to Become One and How to Manage Them. London: Hurst. Nordenstreng, Kaarle. 2012. "The New World Information and Communication Order: An Idea That Refuses to Die." In Media History and the Foundations of Media Studies, Volume 1, The International Encyclopaedia of Media Studies, edited by J. Nerone, 477-499. Oxford: Wiley-Blackwell.

Nordenstreng, Kaarle, and Claudia Padovani. 2005. "From NWICO to WSIS: Another World Information and Communication Order." Global Media and Communication 1 (3): 264-272.

Nordenstreng, Kaarle, and Daya Kishan Thussu, eds. 2015. Mapping BRICS Media. London: Routledge.

Nordenstreng, Kaarle, and Tapio Varis. 1974. Television Traffic-A One-Way Street? A Survey and Analysis of the International Flow of Television Programme Material. Reports and Papers on Mass Communication, No. 70. Paris: UNESCO.

PwC (PriceWaterhouseCooper). 2014. PwC Annual Global Entertainment and Media Outlook. London: PriceWaterhouseCooper.

Roach, Colleen. 1987. "The US Position on the New World Information and Communication Order." Journal of Communication 37 (4): 36-51.

Schaefer, David, and Kavita Karan, eds. 2013. Bollywood and Globalization: The Global Power of Popular Hindi Cinema. London: Routledge.

Schmidt, Eric, and Jared Cohen. 2013. The New Digital Age: Reshaping the Future of People, Nations and Business. London: John Murray.

Seib, Philip, ed. 2012. Aljazeera English: Global News in a Changing World. New York: Palgrave Macmillan.

Shambaugh, David. 2013. China Goes Global: The Partial Power. New York: Oxford University Press. Sherr, James. 2012. Soft Power?: The Means and Ends of Russian Influence Abroad. Washington, DC: Brookings Institution Press.

Sinclair, John, and Joseph Straubhaar. 2013. Television in Latin America. London: BFI. 
Siwek, Stephen. 2014. "Copyright Industries in the U.S. Economy: The 2014 Report." Report prepared for the International Intellectual Property Alliance (IIPA), November. www.iipa.com.

Somavia, Juan. 1976. "The Transnational Power Structure and International Information." Development Dialogue 2: 15-28.

Stockman, Daniela. 2013. Media Commercialization and Authoritarian Rule in China. New York: Cambridge University Press.

Thussu, Daya Kishan. 2007. "Mapping Global Media Flow and Contra-flow." In Media on the Move: Global Flow and Contra-Flow, edited by D. K. Thussu, 11-32. London: Routledge.

Thussu, Daya Kishan. 2013. Communicating India's Soft Power: Buddha to Bollywood. New York: Palgrave/Macmillan.

Thussu, Daya Kishan. 2015. "Digital BRICS: Building a NWICO 2.0?" In Mapping BRICS Media, edited by K. Nordenstreng and D. Thussu, 242-263. London: Routledge.

Thussu, Daya Kishan. Forthcoming. International Communication-Continuity and Change. 3rd ed. New York: Bloomsbury Academic.

UNDP. 2013. The Rise of the South: The 2013 Human Development Report. New York: United Nations Development Programme.

UNESCO. 2009. World Culture Report: Investing in Cultural Diversity and Intercultural Dialogue. Paris: United Nations Educational, Scientific and Cultural Organization.

UNESCO. 2013. Emerging Markets and the Digitalization of the Film Industry. An Analysis of the 2012 UIS International Survey of Feature Film Statistics, August. Paris: UNESCO Institute for Statistics.

Varis, Tapio. 1985. International Flow of Television Programmes, Reports and Papers on Mass Communication, No. 100. Paris: UNESCO.

WAN-IFRA. 2014. Trends in Newsrooms 2014. Paris: The World Association of Newspapers and News Publishers. Accessed 30 July 2015.

World Bank. 2013. Capital for the Future: Saving and Investment in an Interdependent World. Washington, DC: The World Bank.

Zakaria, Fareed. 2008. The Post-American World. London: Allen Lane.

Zhu, Ying. 2012. Two Billion Eyes: The Story of China Central Television. New York: The New Press.

Daya Kishan Thussu (corresponding author) is Professor of International Communication and Co-Director of India Media Centre in the Department of Journalism and Mass Communications at the University of Westminster, London, UK. Email: D.K.Thussu@ westminster.ac.uk 